\title{
EFEKTIVITAS PENERAPAN METODE PEMBELAJARAN KOOPERATIF TIPE JIGSAW DIPADUKAN DENGAN MIND MAP PADA MATA PELAJARAN EKONOMI SMA KELAS X SMA PEMBANGUNAN PADANG
}

\author{
Menik Kurnia Siwi, Murniati \\ UNP \& SMA Pembangunan Padang
}

\begin{abstract}
Abstrak : Penelitian ini bertujuan untuk mengetahui: (1) penerapan metode jigsaw dipadukan dengan metode mind map untuk meningkatkan hasil belajar ekonomi siswa kelas X SMA Pembangunan Padang, dan (2) Seberapa besar peningkatan hasil belajar siswa setelah mendapat metode pembelajaran jigsaw dipadukan dengan mind map. Jenis Penelitian ini merupakan penelitian tindakan kelas (PTK). Pengumpulan data dilakukan dengan tes. Teknik analisis data dilakukan secara kualitatif. Subjek penelitian ini adalah siswa kelas X SMA Pembangunan Padang. Hasil penelitian: (1) hasil prestasi siswa dari prasiklus sampai siklus II banyak mengalami kenaikan hasil prestasi belajar ekonomi siswa kelas X IIS 3 SMA Pembangunan Padang.(2) Hasil belajar siklus I menunjukkan bahwa masih banyak siswa yang belum memperoleh nilai di atas standard kelulusan minimal. Dari 36 siswa, 18 (48,5\%) siswa belum memenuhi SKM dan 17 (51,5\%) siswa yang sudah mampu memenuhi SKM dengan nilai ratarata kelas 61,11. Hasil belajar siswa pada siklus II lebih baik daripada siklus I. dari 36 siswa 31 siswa sudah mampu memenuhi SKM dan 5 orang siswa masih dibawah SKM, sehingga rata-rata kelas 83,8 dengan ketuntasan sebesar 85,7\%.
\end{abstract}

Kata kunci: metode jigsaw, metode mind map, ekonomi. 


\section{PENDAHULUAN}

SMA Pembangunan Padang merupakan Labs School dari Universitas Negeri Padang. Sebagai sekolah laboratorium SMA Pembangunan dituntut untuk selalu memperbaharui setiap komponen di sekolah karena setiap perkembangannya selalu di awasi oleh UNP. Baik dari sisi fasilitas maupun kualitas pembelajaran selalu ditingkatkan. Observasi dan evaluasi pun perlu dilakukan secara berkelanjutan untuk menjaga kualitas sekolah. Kegiatan penugasan dosen di sekolah (PDS) merupakan salah satu cara untuk meningkatkan kualitas pembelajaran di sekolah. Keterlibatan dosen disekolah diharapkan mampu memberikan contoh dan motivasi serta masukan bagi para guru sehingga pada akhirnya dapat terus meningkatkan hasil belajar siswa. Pada saat observasi awal di sekolah ada beberapa masalah mendasar yang terjadi saat proses pembelajaran sedang berlangsung. Beberapa masalah itu antara lain guru yang lebih banyak aktif menjelaskan sementara siswa hanya mendengar sehingga pembelajar jadi pasif. Saat siswa diberi pertanyaan hanya siswa yang bertempat duduk di depan yang aktif meperhatikan dan menjawab pertanyaan guru, sedangkan siswa yang duduk di belakang asyik bermain, berbicara dengan teman sebangku, mencoret-coret buku dan menggambar. Selain itu siswa monoton belajar hanya dari satu sumber yaitu dari buku paket yang dipinjamkan sekolah, sehingga siswa diwajibkan mencatat dan itu membuat siswa bosan dan malas sehingga pada saat ujian mereka tidak memiliki pegangan untuk dipelajari dan hal ini secara tidak langsung menyebabkan hasil belajar siswa rendah. Oleh karena itu, diperlukan perbaikan dalam proses pembelajaran untuk meningkatkan motivasi dan hasil belajar siswa yaitu dengan cara menumbuhkan keinginan siswa aktif di kelas, mencatat lebih baik dan memahami serta mengingat materi yang dijelaskan dengan lebih baik lagi.

Panduan DBE2 melalui program ALIS (Uno \& Muhamad, 2012: 77) memuat beberapa hal yang harus dilakukan oleh guru agar tercipta pembelajaran yang aktif melalui (1) membuat rencana secara hati-hati dengan memperhatikan detail berdasarkan atas sejumlah tujuan yang jelas yang dapat dicapai (2) memberikan kesempatan bagi siswa untuk belajar secara aktif dan mengaplikasikan pembelajaran mereka dengan metode yang beragam sesuai dengan konteks kehidupan nyata siswa, (3) secara aktif mengelola lingkungan belajar agar tercipat suasana yang nyaman, tidak bersifat mengancam, berfokus pada pembelajaran serta membangkitkan ide yang pada gilirannya dapat memaksimalkan waktu, sumber-sumber yang menjamin pembelajaran aktif berjalan, dan (4) menilai siswa dengan cara-cara yang dapat mendorong siswa untuk menggunakan apa yang telah mereka pelajari di kehidupan nyata, dalam hal ini disebut penilaian otentik.

Upaya untuk mengaktifkan siswa di kelas dapat dilakukan salah satunya dengan menerapkan pembelajaran kooperatif yang melibatkan kerjasama dan keaktifan siswa di kelas. Pembelajaran kooperatif merupakan metode pembelajaran yang didasarkan atas kerja kelompok yang dilakukan untuk mencapai tujuan khusus ( Santoso \& Suparno, 2003:5). Terdapat ada beberapa model pembelajaran berbasis belajar kooperatif, antara lain model pembelajaran 
kooperatif Student Teams Achievment Divisions (STAD), Jigsaw, Group Investigation (GI), Numbered Heads Together (NHT) dan Think Pair Share (TPS).

Penelitian ini menggunakan Model Pembelajaran Kooperatif tipe Jigsaw dipadukan dengan Metode Mind Map. Pembelajaran kooperatif tipe jigsaw adalah suatu tipe pembelajaran kooperatif yang terdiri dari beberapa anggota dalam suatu kelompok yang bertanggung jawab atas penguasaan materi belajar dan mampu mengerjakan materi tersebut kepada anggota lain dalam kelompoknya (Arends,1997). Model pembelajaran kooperatif tipe jigsaw merupakan model pembelajaran kooperatif, dengan peserta didik belajar dalam kelompok kecil yang terdiri dari 4-5 orang secara heterogen dan bekerja sama saling ketergantungan yang positif dan bertanggung jawab atas ketuntasan bagian materi pelajaran yang harus dipelajari dan menyampaikan materi tersebut kepada anggota yang lain (Arends, 1997).

Hubungan antara kelompok asal dan kelompok ahli pada kooperatif jigsaw dapat dilihat pada Gambar 2.2 berikut.

\section{Kelompok Asal}

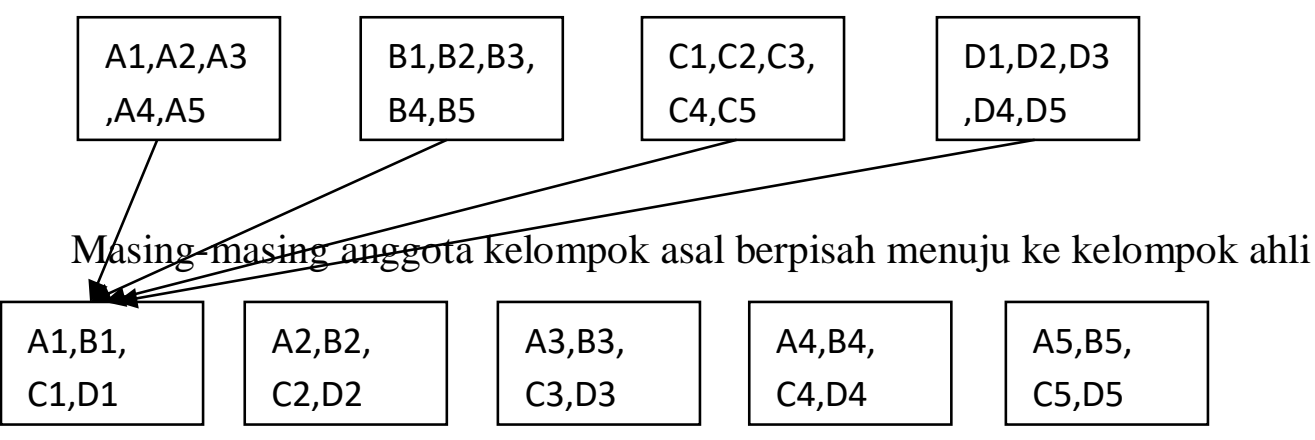

\section{Kelompok Ahli}

Gambar 2.2 Kelompok Asal dan kelompok Ahli pada Kooperatif Jigsaw

(Sumber modifikasi dari: Kilic, 2008:111)

Peta pikiran (Mind Map) adalah cara termudah menempatkan informasi ke dalam otak dan mengambil informasi ke luar dari otak (Buzan, 2006:4). Peta pikiran ini didasarkan pada riset tentang bagaimana cara kerja otak sebenarnya, dimana otak berfungsi untuk mengatur dan menyimpan informasi. Hal ini disebabkan karena otak manusia seringkali mengingat informasi dalam bentuk gambar, symbol, suara, bentuk-bentuk, dan perasaan (Bobbi \& Hernacki, 1992: 152). Peta pikiran memiliki banyak manfaat yaitu membantu dalam mengingat, mendapatkan ide, menghemat waktu, berkosentrasi, mendapatkan nilai yang lebih bagus, mengatur pikiran dan hobi, media bermain, bersenang-senang dalam menuangkan imajinasi yang tentunya memunculkan kreativitas (Gardu Guru, 2008). Apabila menggunakan model pembelajaran peta 
pikiran, siswa dapat menggunakan otak kiri untuk berpikir dan menggunakan otak kanan untuk menulis dan menggambar sehingga siswa belajar dengan melibatkan kedua belah otak.

Berdasarkan latar belakang masalah di atas, maka peneliti memutuskan untuk melakukan penelitian tentang efektivitas penerapan metode pembelajaran kooperatif tipe Jigsaw dipadukan dengan mind map pada mata pelajaran ekonomi SMA kelas X SMA Pembangunan Padang.

\section{METODE PENELITIAN}

Arikunto (2010:137) menyatakan bahwa penelitian ini menggunakan desain Penelitian Tindakan Kelas (PTK). Penelitian tindakan kelas merupakan suatu pencermatan terhadap kegiatan belajar berupa sebuah tindakan, yang sengaja dimunculkan dan terjadi dalam sebuah kelas secara bersama. Arikunto (2012:3) menjelaskan pengertian penelitian tindakan kelas itu sendiri antara lain (a) penelitian menunjuk pada suatu kegiatan mencermati suatu objek dengan menggunakan cara dan aturan metodologi tertentu untuk memperoleh data atau informasi yang bermanfaat dalam meningkatkan mutu suatu hal menarik minat dan penting bagi peneliti, (b) tindakan menunjuk pada sesuatu gerak kegiatan yang sengaja dilakukan dengan tujuan tertentu, dan (c) kelas dalam hal ini tidak terikat pada pengertian ruang kelas, tetapi dalam pengertian yang lebih spesifik.

Berdasarkan dari tujuannya, PTK dilaksanakan untuk mengadakan perbaikan dan peningkatan pelaksanaan pembelajaran yang ada di kelas dan hasilnya tidak untuk digeneralisasikan. Prosedur dan langkah-langkah dalam penelitian tindakan kelas ini mengikuti prinsip dasar penelitian tindakan yaitu menggunakan prosedur kerja dengan satu siklus, yang terdiri dari empat langkah yaitu perencanaan tindakan (Plan), pelaksanaan (action), observasi (observation), dan refleksi (reflection). Secara umum alur pelaksanaan tindakan dalam penelitian tindakan kelas ini digambarkan pada gambar berikut. 


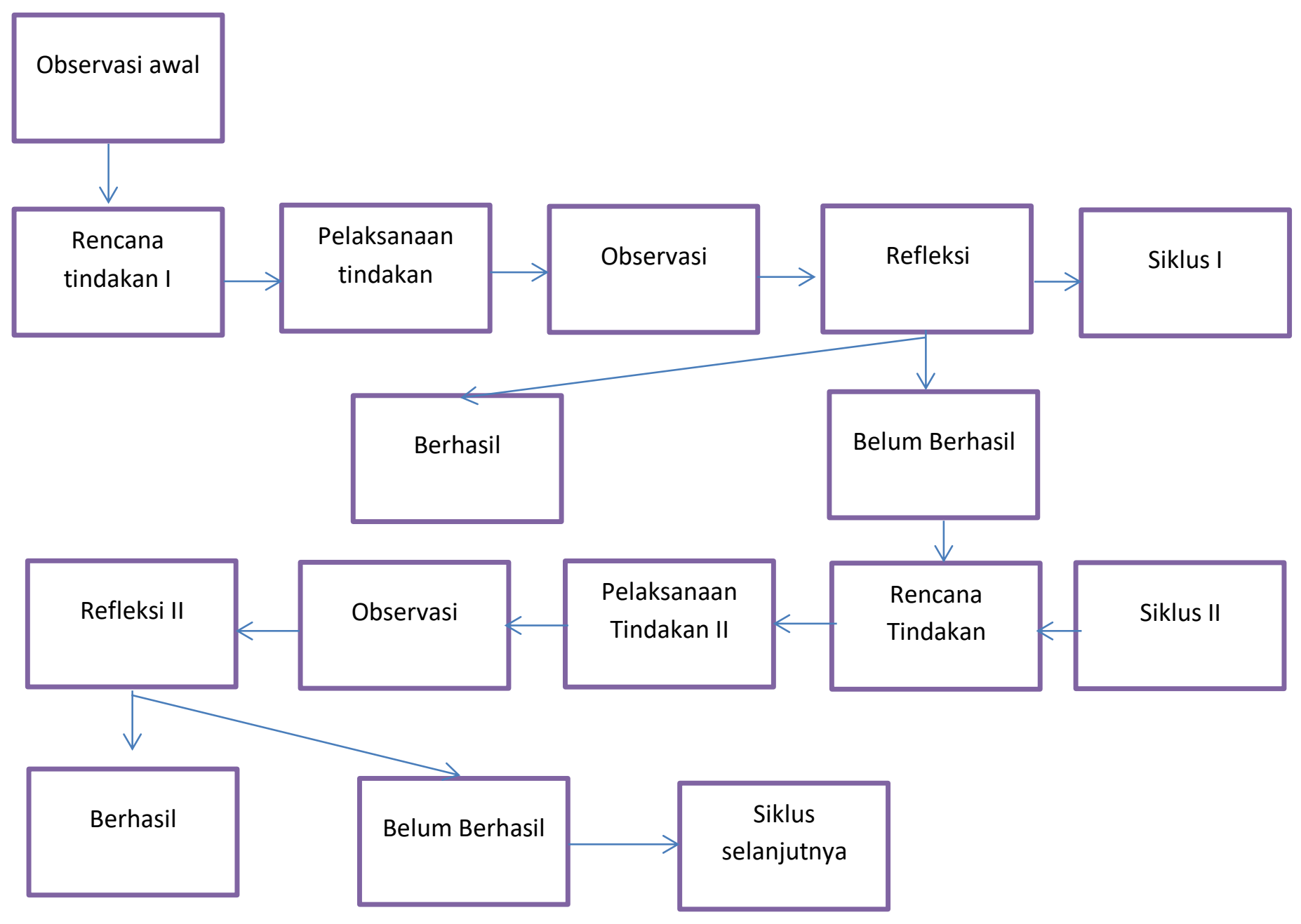

Gambar 1. Siklus PTK

Penelitian ini dilaksanakan di SMA Pembangunan Padang dengan subjek penelitian siswa kelas X IIS3 yang terdiri dari 36 siswa. Teknik pengumpulan data adalah tes, wawancara dan observasi. Teknik analisis yang digunakan dalam penelitian ini terdiri dari tiga tahap yaitu reduksi data, penyajian data, dan penarikan kesimpulan. (Moleong, 2000).

\section{HASIL dan PEMBAHASAN}

\section{SIKLUS I}

Perencanaan tindakan didahului dengan proses wawancara dan observasi untuk mengetahui motivasi, hasil belajar siswa, serta proses belajar mengajar sebelum menggunakan model 
pembelajaran kooperatif tipe jigsaw dipadukan dengan Mind Map. Berdasarkan hasil wawancara dan observasi tersebut peneliti menyusun rencana pembelajaran sebagai pedoman dalam pelaksanaan tindakan pada siklus I.

Tabel I. Rencana Pembelajaran Siklus I

\begin{tabular}{|c|c|}
\hline O & uru \\
\hline 1 & $\begin{array}{l}\text { egiatan awal } \\
\text { Guru membuka pelajaran dengan mengucapkan salam dan mempresensi } \\
\text { siswa } \\
\text { Guru menjelaskan kompetensi dasan dan indicator yang hendak dicapai } \\
\text { serta tujuan pembelajaran. } \\
>\text { Guru menggali pengetahuan awal yang dimiliki siswa } \\
>\text { Guru membentuk kelompok, tiap kelompok terdiri dari } 4-5 \text { anggota } \\
\text { kelompok }\end{array}$ \\
\hline 2 & $\begin{array}{l}\text { Kegiatan inti } \\
\text { Guru memberikan materi pada kelompok, dan memberikan tugas untuk } \\
\text { diidentifikasi } \\
\text { Guru membimbing siswa dalam kelompok untuk mengidentifikasi masalah } \\
\text { dan melakukan penyelidikan masalah } \\
\text { Guru menyuruh siswa untuk membentuk mind map untuk dijelaskan ke } \\
\text { anggota kelompok asal. } \\
\text { Caranya yaitu: } \\
\checkmark \text { Memulai dari bagian tengah kertas kosong yang sisi panjangnya } \\
\text { dietakkan dengan posisi mendatar. Tema pokok dituliskan di } \\
\text { tengah karena memberikan kebebasan otak untuk menyebar ke } \\
\text { segala arah. } \\
\checkmark \text { Menggunakan foto atau gambar untuk ide sentral } \\
\checkmark \text { Menggunakan warna dan tema mind map } \\
\quad \text { Mengbubungkan cabang-cabang dari topic utama ke setiap gagasan } \\
\quad \text { dan seterusnya } \\
\text { menggunakan kata kunci untuk setiap cabang atau garis agar } \\
\text { mudah diingat } \\
\text { Guru meminta kelompok ahli kembali ke kelompok asal untuk } \\
\text { menjelaskan apa yang diperoleh ketika diskusi dengan kelompok ahli } \\
\text { Guru meminta siswa membuat mind map dari hasil diskusi dengan } \\
\text { kelompk asal } \\
\text { Guru meminta setiap kelompok untuk mempresentasikan mind map hasil } \\
\text { diskusi di depan kelas }\end{array}$ \\
\hline 3 & $\begin{array}{l}\text { enutup } \\
>\text { Guru melakukan review dan membuat kesimpulan bersama } \\
>\text { Guru memberikan post test } \\
>\text { Guru menyampaikan materi yang akan dipelajari pada pertemuan } \\
\text { berikutnya } \\
>\text { Guru menutup pelajaran dan memberi salam. }\end{array}$ \\
\hline
\end{tabular}


Hasil belajar siklus I menunjukkan bahwa masih banyak siswa yang belum memperoleh nilai di atas standard kelulusan minimal. Dari 36 siswa, 18 (48,5\%) siswa belum memenuhi SKM dan 17 (51,5\%) siswa yang sudah mampu memenuhi SKM dengan nilai rata-rata kelas 61,11. Merefleksikan hasil dari siklus I, maka peneliti merancang siklus II untuk memperbaiki kekurangan yang terjadi pada siklus I.

\section{SIKLUS II}

Hasil refleksi siklus I dipedomani dalam rangka menyusun perencanaan tindakan pada siklus II. Berikut rencana pembelajaran yang dilakukan pada siklus II.

Tabel 2. Rencana Pembelajaran Siklus II

\begin{tabular}{|c|c|}
\hline No & egiatan Guru \\
\hline 1 & $\begin{array}{l}\text { Kegiatan awal } \\
>\text { Guru membuka pelajaran dengan mengucapkan salam dan mempresensi } \\
\text { siswa } \\
>\text { Guru menjelaskan kompetensi dasan dan indicator yang hendak dicapai } \\
\text { serta tujuan pembelajaran. } \\
>\text { Guru menggali pengetahuan awal yang dimiliki siswa } \\
>\text { Guru membentuk kelompok, tiap kelompok terdiri dari } 4-5 \text { anggota } \\
\text { kelompok }\end{array}$ \\
\hline 2 & $\begin{array}{l}\text { Kegiatan inti } \\
>\text { Guru memberikan materi pada kelompok, dan memberikan tugas untuk } \\
\text { diidentifikasi } \\
>\text { Guru membimbing siswa dalam kelompok untuk mengidentifikasi masalah } \\
\text { dan melakukan penyelidikan masalah } \\
>\text { Guru menyuruh siswa untuk membentuk mind map untuk dijelaskan ke } \\
\text { anggota kelompok asal. } \\
\text { Caranya yaitu: } \\
\checkmark \text { Memulai dari bagian tengah kertas kosong yang sisi panjangnya } \\
\quad \text { dietakkan dengan posisi mendatar. Tema pokok dituliskan di } \\
\quad \text { tengah karena memberikan kebebasan otak untuk menyebar ke } \\
\quad \text { segala arah. } \\
\checkmark \text { Menggunakan foto atau gambar untuk ide sentral } \\
\checkmark \text { Menggunakan warna dan tema mind map } \\
\quad \text { dangbubungkan cabang-cabang dari topic utama ke setiap gagasan } \\
\checkmark \text { Menggunakan kata kunci untuk setiap cabang atau garis agar } \\
\text { mudah diingat } \\
>\text { Guru meminta kelompok ahli kembali ke kelompok asal untuk } \\
\text { menjelaskan apa yang diperoleh ketika diskusi dengan kelompok ahli } \\
>\text { Guru meminta siswa membuat mind map dari hasil diskusi dengan } \\
\text { kelompk asal } \\
>\text { Guru meminta setiap kelompok untuk mempresentasikan mind map hasil } \\
\text { diskusi di depan kelas }\end{array}$ \\
\hline
\end{tabular}




\begin{tabular}{|l|l|l|}
\hline 3 & Penutup \\
& $>$ Guru melakukan review dan membuat kesimpulan bersama \\
& $>$ Guru memberikan post test \\
& $>$ Guru menyampaikan materi yang akan dipelajari pada pertemuan \\
& $>$ berikutnya \\
& $>$ Guru menutup pelajaran dan memberi salam.
\end{tabular}

Hasil belajar siswa pada siklus II lebih baik daripada siklus I. dari 36 siswa 31 siswa sudah mampu memenuhi SKM dan 5 orang siswa masih dibawah SKM, sehingga rata-rata kelas 83,8 dengan ketuntasan sebesar $85,7 \%$.

Menurut Dimyati \& Mundjiono (2006:169), program pemebelajaran kelompok memberikan tekanan utama pada peningkatan kemampuan individu sebagai anggota kelompok. Oleh sebab itu penilaian yang dilakukan pada kelompok buka penilaian secara individu melainkan penilaian secara kelompok. Peningkatan kemampuan individu tersebut ditunjukkan dengan keberhasilan anggota kelompok dalam mencapai tujuan pembelajaran yang berupa ketuntasan hasil belajar. Pada pembelajaran kooperatif, keberhasilan kelompok sangatlah penting. Untuk mencapai hal tersebut harus didukung oleh keberhasilan individu sebagai anggota kelompok. Semakin besar tingkat keberhasilan kelompok tersebut dalam melaksanakan pembelajaran kooperatif maka semakin banyak anggota kelompok yang tuntas belajar. Pada siklus I terdapat 17 siswa yang tuntas belajar dan pada siklus II terdapat 31 siswa yang sudah tuntas belajar.

Peningkatan hasil belajar yang terjadi pada siklus II sehingga ketuntasan belajar dapat tercapai dipengaruhi oleh beberapa hal antara lain: (1) siswa memperhatikan penjelasan yang diberikan guru maupun temannya ketikan melakukan diskusi kelompok; (2) siswa belajar menyelesaikan tugas dengan membuat peta pikiran dan mengerjakan tugas sesuai dengan waktu yang disediakan; (3) siswa berdiskusi dan belajar dengan sungguh-sungguh tentang materi yang sedang dipelajari untuk menyelesaikan semua tugasnya; (4) siswa belajar dengan gembira, menunjukkan sikap semangat dan senang, serta tidak melamun saat proses belajar mengajar berlangsung; (5) siswa mengerjakan semua tugas termasuk di luar sekolah yang telah diberikan guru yaitu dengan memanfaatkan jam istirahat untuk melanjutkan diskusi maupun mengerjakan tugas; (6) pada saat kegiatan diskusi, siswa tampil presentasi ayau berkomunikasi dengan temannya dengan sangat tenang (tidak gugup) dan (7) siswa mempunyai sika percaya diri ketika mengerjakan Post tes dengan kemampuan dirinya sendiri sehingga tidak mudah terpengaruh oleh siswa yang lain.

\section{KESIMPULAN dan SARAN}


Berdasarkan hasil dari perhitungan analisis data dan sesuai rumusan pada hipotesis, dapat diketahui penerapan model pembelajaran kooperatif tipe jigsaw dipadukan dengan mind map dapat meningkatkan hasil belajar ekonomi siswa kelas IIS 3 SMA Pembangunan Padang. Hal tersebut ditandai dengan peningkatan hasil belajar siswa yang ditandai dengan peningkatan hasil belajar siswa yang diperoleh sebelum pemberian tindakan dan hasil belajar siswa setelah melakukan siklus I dan Siklus II.

Saran yang dapat peneiliti berikan terkait penerapan pembelajaran kooperatif tipe jigsaw dipadukan dengan mindmap adalah saran untuk guru sebaiknya menjelaskan manfaatn dan aturan main model dengan sangat jelas disertai gambar agar siswa mengerti tugas individu dna tugas kelompok yang harus dikerjakan. Dengan demikian pembelajaran akan berlangsung lancar, menyenangkan dan penggunaan waktu secara optimal sesuai dengan rencana pembelajaran yang telah disusun.

\section{DAFTAR PUSTAKA}

Arends, I Richard. 1997. Clasroom Instruction and Management. Newyork: The Mc Graw- Hill Company.

Arends, I Richard. 2008. Learning to Teach. Edisi Ketujuh. New York: Mc Graw Hill Companies.

Arikunto,S.2006. Prosedur Penelitian Suatu Praktek. Jakarta: PT Rineka Cipta.

Buzan, Toni.2006. Buku Pintar Mind Map. Jakarta: Gramedia

DePorter,B, Reardon, M \& Singer-Nourie, S.1999.Quantum Teaching: Mempraktikan Quantum Learning di Ruang-Ruang Kelas. Terjemahan oleh Ari Nilandri.2000.Bandung: Kaifa.

Dimyati \& Mudjiono.2002. Belajar dan Pembelajaran. Jakarta: Proyek Pembinaan Peningkatan Mutu Tenaga Kependidikan. Dikti.

Gardu Guru. 2008. Pembelajaran Dengan Peta Pikiran. (online)

Kilic, D.2008. The Effect Of Jigsaw Technique on Learning the Concepts of the Principles and method of Teaching. World Applied Science Journal 4 (Supple 1): 109-114.

Moleong, Lexy.J. 2000. Metodologi Penelitian Kualitatif. Bandung: Remaja Rosdakarya

Slameto. 2003. Belajar dan faktor-faktor yang mempengaruhinya. Jakarta : Rineksi Cipta.

Sudjana, N. 2001. Penilaian Hasil Proses Belajar Mengajar. Bandung: remaja Rosdakarya

Winkel, W.S. 1996. Psikologi Pengetahuan. Jakarta: Grasindo. 
